\title{
Recommendations of 5th-grade Medical Faculty students about clinical anatomy course
}

\section{Tıp Fakülltesi 5. sınıf öğrrencilerinin klinik anatomi dersi hakkındaki görüşleri}

\author{
Vedat Sabancıoğullarıı ${ }^{1}$, Kaan Çimen ${ }^{1}$, Güildal Doğruyol ${ }^{1}$, Yaşar Taştem urr ${ }^{1}$, İllhan Otağ ${ }^{1}$, Muhittin \\ Sönmez ${ }^{1}$, Mehmet Cimen ${ }^{1}$
}

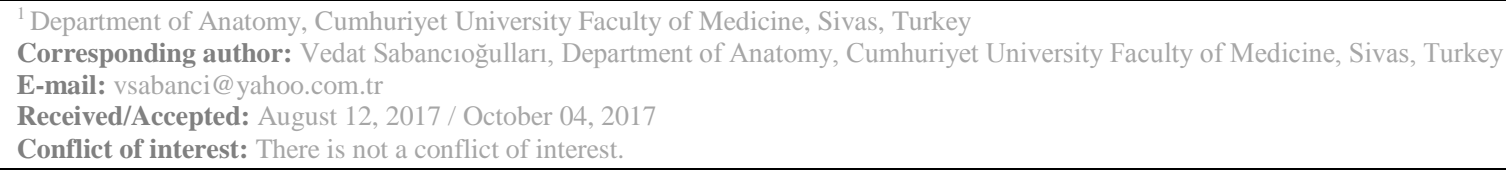

\begin{abstract}
SUMMARY
Objective: The data gathered objectively, and the information which is evidence-based is essential in evaluating both the sufficiency and the efficiency of medical education. Especially the feedback of students insights and suggestions is a good guidance for management of medical training. In this context, in the present study, it has been aimed to determine the thoughts and recommendations of 5th-grade Medical Faculty Students about Clinical Anatomy Course (CAC) by using a questionnaire which is consist of 12 questions.
\end{abstract}

Method: A hundred and forty-four student ( 81 female and 63 male) volunteered to participate the study and took the questionary.

Results: While $86.8 \%$ of the students mentioned that it would be more necessary to take Clinical Anatomy Course during Orthopedics Course, $87.5 \%$ of the student showed their preference for Neurosurgery Course. $75.7 \%$ of the students suggested that it would also be beneficial to add CAC into the Eye Diseases and Otorhinolaryngology Practise in addition to those practices mentioned above.

While the allotted time for CAC in the Clinical Practice was found sufficient to only $39.6 \%$ of the student, $31.9 \%$ asked for an increase in duration of CAC. According to $71.5 \%$ of the students, the information should be solidified after the theoretical lectures by practices in which bones, manikins, and cadavers are used effectively. Giving attendance is not favored by $50 \%$ of the students, and almost same amount of the participants (51.4\%) thinks the exam at the end of the class or the course is unnecessary.

Conclusions: It has been understood from the positive feedback of the students that CAC which is currently taken during Orthopedics and Neurosurgery Courses facilitates the understanding Clinical Practise topics and it increases the overall success of the students in Clinic. While preparing the medical training curriculum, adding the CAC into the clinical training curriculums when needed may help to increase the overall quality of the medical education.

Keywords: Clinical anatomy, questionnaire, medical education.

\section{ÖZET}

Amaç: Tıp eğitiminin yeterliliğinin ve etkinliğinin değerlendirilmesinde somut veriler ve kanıta dayalı bilgiler önemlidir. Özellikle öğrencilerin görüş ve önerilerinin alınması tıp eğitiminin yönlendirilmesinde yol gösterici olmaktadır. Bu sebeple, çalışmamızda oniki sorudan oluşan anket formu uygulanarak, C.Ü. tıp fakültesi beşinci sınıf öğrencilerinin klinik anatomi dersi hakkındaki düșünceleri ve önerilerinin belirlenmesi amaçlanmıștır.

Yöntem: Çalışmaya anket sorularını cevaplamayı kabul eden 81'i kadın, 63'ü erkek 144 gönülllü öğrenci dahil edildi. Bulgular: Öğrencilerin \% 86.8'i ortopedi, \% 87.5'i beyin cerrahi stajları içerisinde verilmekte olan klinik anatomi dersinin gerekli olduğunu düşünürken, \%75.7'si bu stajlara ek olarak özellikle göz ve KBB stajları içerisinde de klinik anatomi dersinin faydalı olacağını belirtmiștir.

Stajlar içerisinde klinik anatomi dersi için ayrılan süreyi öğrencilerin \% 39.6'sı yeterli bulurken, \%31.9'u ders saatlerinin arttırılmasını istemiştir. Öğrencilerin \% 71.5'ine göre teorik derslerden sonra kemik, maket, kadavra üzerinde yapılan uygulama dersleriyle konular pekiştirilmedir. Öğrencilerin \% 50'si derslerde yoklama alınmasını istemez iken, \%51.4’ü ders bitiminde ya da staj sonunda sınav yapılmasına gerek olmadığını ifade etmiştir.

Sonuç: Öğrencilerden alınan pozitif geribildirimler göstermektedir ki halen ortopedi ve beyin cerrahi stajları içerisinde verilen klinik anatomi dersi, staj konularının anlaşılmasını kolaylaştırmakta ve başarıyı arttırmaktadır. Eğitim programları 


\section{INTRODUCTION}

It is still unclear and arguable how the education should be in Medical Faculties and which educational models would be more efficient to reach the aims. The anatomy lesson which is one of the most important and fundamental parts of the medical education is also in the middle of these debates and the efforts in improving anatomy education is in progress ${ }^{1}$. Anatomy lesson is cataloged under Basic Medical Science, and the lesson is included in the curriculum mostly in the first two grades ${ }^{2,3}$.

Besides, the internship groups in Orthopedics and Neurosurgery Departments which wished for additional clinical anatomy course in their program could have been able to get supplementary anatomy lectures in our medical faculty since 2014 . The CAC has been given at the first week the Clinical Practice. By this way, students can recall the basic anatomic information which will create a basis for further clinical topics and facilitate the learning process.

It is very common in the modern systems to use student feedbacks in order to determine the level in the teaching-learning process. The comments taken from the medical students about their education system during their education process is essential to do further plannings about the context and methods of the current curriculum ${ }^{4-6}$.

So that reason, it has been aimed in the present study to determine the thoughts of 5th grade Cumhuriyet University Medical Faculty Students about clinical anatomy course by using a questionnaire consist of 12 questions.

\section{MATERIAL AND METHODS}

A hundred and forty-four 5th grade student who have taken CAC in Cumhuriyet University Medical Faculty in 2016-2017 Academic Year and volunteered to participate the study and take the questionary included to our study. A questionary consist of 12 open ended questions have been used in the present study. The participants are given the option not to put their name on the paper be anonymous to let them express their opinions more openly, and objectively. It has been aimed to increase the reliability of the study with this anonymity. Data were analyzed by using SPSS package program (v15).

\footnotetext{
The questionary is consist of following questions;

1. Do you think CAC should be given during Orthopedics Course?

2. Do you think CAC should be given during Neurosurgery Course?

3. Do you find the duration of CAC enough which is currently provided in Orthopedics and Neurosurgery Courses?

4. Do you think an exam is necessary after the CAC? if you believe that an exam is needed, can the questions be added to the main exam which is made for the Clinical Practice?
}

5. Do you think attendance should be taken during CAC?

6. Are you satisfied with the contents of the CAC lessons? Are your expectations satisfied by the contents of the CAC lessons?

7. How should theoretical lessons have proceeded?

8. Should theoretical lessons be followed by practice?

9. If the answer to the 8th question, what should be the proper materials for the practice?

10. Should CAC be added into other Clinical Practises as it exists in Orthopedics and Neurosurgery Courses?

11. Should the cross-sectional anatomy lesson be added into CAC?

12. Should anatomy lectures which are design to improve the medical specialty Exam (TUS) success be added into the 6th-grade curriculum? 


\section{RESULTS}

The mean age of the participants ( 81 female and 63 male) was 23.76. While 125 students $(86.8 \%)$ mentioned that it would be more necessary to take Clinical Anatomy Course during Orthopedics Course, 126 students $(87.5 \%)$ showed their preference for Neurosurgery Course. Although, 29 students $(20.1 \%)$ thought that there is no need for CAC in these Clinical Practises. While for 57 students $(39.6 \%)$ the lecture hours for CAC is sufficient, 46 students asked for an increase in lecture hours of CAC. An exam at the end of the course has been seen as necessary for 50 students (34.7\%). On the other hand, 74 students $(51.4 \%)$ thought that there is no need for an exam. Most of the students (72 students, $50 \%$ ) do not want to give attendance in the lectures, 58 students $(40.3 \%)$ think that attendance is necessary to keep the integrity of the lectures. In one hand, 88 students $(61.1 \%)$ agree that the content of the CAC is good enough to address their expectations, on the contrary, 66 students $(45.8 \%)$ request for mix presentation techniques including making students take notes, power point presentation, and verbal presentations. A considerable amount of the students (103 students, $71.5 \%$ ) wants to solidify the information they took from theoretical lectures with bones, manikins, and cadavers right after the lectures. 109 students think that having CAC in Eye Diseases and Otorhinolaryngology Practise in addition to the Orthopedics and Neurosurgery Courses would be useful. Hence the number of the students who want to get cross-sectional anatomy were $105(72.9 \%)$. Although there were 72 students $(50.7 \%)$ who want to get anatomy lectures in 6th grade to improve their skills for TUS exam, 44 students $(30.6 \%)$ thought that they do not need such specific training. Meanwhile, 27 students $(18.8 \%)$ were hesitant about this controversial topic.

\section{DISCUSSION}

The feedback taken from the medical students during the medical training is important to manage the medical education programs. In the institutional educational structuring, bilateral communication is essential to have a valid and qualified education program which is being planned to apply. The student is as much important as the teacher during the course of preparing successful education program. The feedbacks are the most valuable tool for the students to reflect their thoughts and experiences $^{4-6}$.

The feedbacks given by the participating students of the current project includes significant clues which reflect the efficiency of the CAC in practice.
125 students $(86.8 \%)$ mentioned that it would be more necessary to take Clinical Anatomy Course during Orthopedics Course, 126 students $(87.5 \%)$ showed their preference for Neurosurgery Course. This findings may indicate that the lectures given at the first week of the Orthopedics Course including lower extremity, upper extremity, vertebral column bones, and joints facilitate the understanding of the students about orthopedic diseases and increases the overall success of the student in the Orthopedics Course. The higher demand for CAC in Neurosurgery Course may indicate that the content of CAC addresses the expectations and become useful. Furthermore, the fact that $61 \%$ of the students mention that the content of the CAC meets their expectations support this theory. Besides that, $45.8 \%$ of the participants request for mix presentation techniques including making students take notes, power point presentation, and verbal presentations.

In a questionary in which 2nd grades of 103 medical faculties included, Ozdemir et al. show that students want to have more clinical information in traditional anatomy lectures. This significant finding may demonstrate the interest of the students for clinical anatomy, and such lesson may be useful especially in higher grades of the medical faculty. In the same study, almost the half of the students wish for an increase in practice hours for anatomy lessons, another important part of the students wants training hours to be used more efficiently ${ }^{7}$.

In the present study, 103 students $(71.5 \%)$ want to solidify the information they took from theoretical lectures with bones, manikins, and cadavers right after the lectures. Though students seem to be happy about the theoretical part of the lectures, they think that they would be able to understand lectures with practice after the lecture and expect for the additional laboratory lessons in the program.

The evaluation of the clinical anatomy lesson differs from one clinic to another. In the Orthopedics Course, questions are sent to the Orthopedics Clinic Chef, and the students answer these questions along with the orthopedics questions before the oral exam. In the Neurosurgery Course, anatomist makes a quiz just after the lecture, and the grades are given to the Clinic Chef of the Neurosurgery. In regard to making exams after lectures, an exam has been seen as necessary for 50 students $(34.7 \%)$. On the other hand, 74 students $(51.4 \%)$ thought that there is no need for an exam. Most of the students (72 students, $50 \%$ ) do not want to give attendance in 
the lectures, 58 students (40.3\%) think that attendance is necessary.

In a study conducted by Ari and Sendemir, $73 \%$ of the students who are recruited to the study from the 4th and 6th grade of 279 medical faculties mentioned that they might consider getting anatomy lectures at the 4th and 5th grades. In the same study, $82.1 \%$ of the participants wanted to get anatomy lectures completely as clinical anatomy lessons, 47.1 of the students thought that getting anatomy lessons with the clinic lessons would be the best way to understand anatomy ${ }^{1}$.

In a questionary made by Acuner et al. $77.43 \%$ of the participants shared the idea that clinical anatomy, cross-sectional anatomy, and radiologic anatomy should be added to the program ${ }^{8}$. Ari et al. found a number of the students who want to get anatomy course once again in the 4th grade as 60.2 $\%$. When the clinical portion of the anatomy education is questioned, $67 \%$ of the students expressed their desire to get their anatomy education completely in the clinics. When the students are asked if there will be a gain in giving anatomy education at the clinics, $90.1 \%$ of the students responded positively to this approach ${ }^{9}$.

Buyukmumcu et al. stated that the inclusion of clinical information on the course slides used in the practical training of anatomy will contribute to the anatomy education significantly ${ }^{10}$. It is important to evaluate the feedbacks of the students objectively and to return the findings to the education positively. We believe that the student feedbacks provided by our study will have positive effects on the management of the education programs and similar feedback evaluations are needed to improve overall medical education.

\section{REFERENCES}

1. Arı İ, Şendemir E. Anatomi eğitimi üzerine öğrenci görüşleri. Uludağ Ü. Tıp Fak. Dergisi 2003; 29: 11-4.

2. Stephen WC, Wojciech P. Animated Powerpoint as a tool to teach anatomy. The anatomical record (New Anat.) 2000; 261: 83-8.

3. Carmichael SW, Pawlina W: Animated powerpoint as a tool to teach anatomy. Anat Rec 2000; 261: 83-8.

4. Şendemir E, Çimen A, Arı İ: Kadavra uygulamaları sirasinda maruz kalınan formaldehitin öğrenciler üzerindeki etkisi. Uludağ Üniv. T1p Fak. Der 1994; 21: 107-10.

5. Cankur NŞ, Turan S: Öğrencilerin bakış açısı ile Tıp Fakültesi eğitimi: I. Eğitim boyutu. Uludă̆ Üniv. Tip Fak. Der 2000; 26: 13-7.

6. Bingöl A: Tiptaki öğretim üyesinin öğretim sorumluluğu. Ankara Üni. Tip Fak. Mec 1999; 52: 181-9.

7. Özdemir ST, Cankur NŞ, Kurt MA. Tıp Fakültesi Öğrencilerinin Anatomi Uygulamaları Hakkındaki Görüşleri: Bir Geri Bildirim Örneği. Uludağ Üniversitesi Tıp Fakültesi Dergisi 2001; 27 (1-2-3): 39-42.

8. Acuner AM, Yalçın M, Ersoy M, Tekdemir İ, Ersoy F. Ankara üniversitesi tıp fakültesi anatomi dersine ilişkin öğretme-öğrenme sürecinin değerlendirilmesi. Ankara Üniversitesi Tip Fakültesi Mecmuasi 1999; 52: 211-8.

9. Arı İ, İrgil E, Kafa İM, Şendemir E. Bir anket Çalışması: Anatomi Eğitimi ve Öğrencilerin Düşünceleri. Uludağ Üniversitesi Tıp Fakültesi Dergisi 2003; 29: 15-8.

10. Büyükmumcu M, Aydın AD, Akın D, Yılmaz MT, Bodur AS. Tip fakültesi öğrencilerinin anatomi pratik derslerinde kullanılan pratik ders slaytları hakkındaki görüşleri. Selçuk Tıp Dergisi 2013; 29: 71-4. 